NAMES, Vol. 68 No. 4, December 2020, 222-237

\title{
Geographical Accuracy of Place-Based Collegiate Athletic Conference Names in the United States
}

\author{
Michael D. Sublett (D) \\ Department of Geography, Geology, and the Environment, Illinois State \\ University, Normal, IL, USA
}

College athletic competition constitutes a significant aspect of life in the United States. Virtually, every institution of higher learning fields intercollegiate teams in a multitude of sporting activities. Most colleges and universities join an organization, a conference of similar institutions, to enhance competition. Some also join single-sport conferences in order to participate in sports that their principal conferences do not accommodate. All conferences have names, often place-based names. Many place-based names convey their conference locations well; others fail in this regard. This essay examines the names of all 184 baccalaureate-level conferences in the United States, excludes those conference names that do not have a place basis, and divides the remaining conferences into two categories: those whose names are place appropriate and those that are not.

KEYWORDS United States, college athletics, athletic conference names

\section{Introduction}

Sportswriter Frank Deford (2OI2) said, “... as badly as athletic conferences flunk arithmetic, they do no better with geography" (para. 2). On the arithmetic side, Deford was referring to conferences whose names include a number that no longer matches the count of colleges in the conferences, like the Big Ten Conference with its 14 members. As for geography, he was hinting that conferences' place-based names may mislead with respect to the spatial configuration of their member schools. This essay examines the names of all I 84 baccalaureate-level conferences in the United States, excludes those conference names that do not have a place basis, and divides the remaining conferences 
into two categories: those whose names are place appropriate and those that are not.

Collegiate conference names matter to member schools' students, faculty, staff, alumni, and general fans, and to those who would profit from the competition that conferences engender and enhance. Having a name in which conference schools can take pride and from which perhaps gain remuneration is noteworthy. Having a name that is outdated from the perspective of where the name suggests member schools occur and where they actually are can be misleading and off-putting. A conference whose name at one time accurately defined its sphere of athletic competition can become frozen and outdated as the membership roll of the conference shifts to accommodate new entrants and says farewell to those schools that depart. Such incongruity is the case as well with place names that no longer reflect the wishes of the population that occupies the area or the landscape characteristics that might have suggested the now outdated name. Just as a place name can be an onomastic mismatch, so can a collegiate athletic conference name. Keep the name and endure the mismatch or update the name and forgo the name's legacy?

\section{Background}

Athletic conferences exist in large measure to enhance athletic competition though not all conferences have had an athletic connection. Religious denominations in the United States have divided their territories into named conferences. Southern Conference was among the Congregational Church's divisions of Berkshire County, Massachusetts, as a local newspaper reported (Pittsfield (Massachusetts) Sun I 828). Indiana Methodists in the I 850 os had a Northwest Conference (Summit County (Akron, Ohio) Beacon I857) and a South-Eastern Conference (Cincinnati Daily Press I 859). Unitarians recognized both an Obio Valley Conference (Courier-Journal (Louisville, Kentucky) I 867) and a Missouri Valley Conference in the I86os (Christian Repository (Montpelier, Vermont)) I 868). Nonsectarian groups like the Atlantic Coast Conference of yachting clubs (The New York Times I906), Lone Star Conference of journeymen stone cutters (El Paso Herald I909), and Mountain-West Conference of electrical and electronic engineers (Tucson Daily Citizen I97I) also have used "conference" in their names.

Voluntary agreements to manage athletic competition among college students at different institutions began around the time of the American Civil War (Smith 20II). Harvard, Yale, Brown, and other nearby colleges sponsored rowing regattas prior to the War and afterward formalized competition by creating the Rowing Association of American Colleges in I870. Following in I 875 came the Intercollegiate Association of Amateur Atbletes, which tried to standardize track and field meets. Seeking consensus on rules different from those of English rugby, the Intercollegiate Football Association appeared in I876. The College Baseball Association launched in 1879 in an attempt to address the conundrum 
Table 1. Collective Terms for Athletic Conferences of Four Year Colleagues and Universities in the United States, 2019-2020

\begin{tabular}{lcc}
\hline Collective term & Number in each category & Percent of 184 \\
\hline Conference & 140 & 76 \\
Association & 29 & 16 \\
League & 13 & 9 \\
Alliance & 1 & $<1$ \\
Federation & 1 & $<1$ \\
No collective term & 1 & $<1$ \\
TOTAL & 185 & \\
\hline
\end{tabular}

Note: Total exceeds 184 because one conference uses conference and league.

about paying collegiate baseball players. Multi-sport agreements began in I894 with the Southern Intercollegiate Athletic Association (Smith 20II). Table I reveals that "conference" is by far the preferred collective term today for such athletic organizations, with the older "association" falling well behind into second place, but ahead of "league," "alliance," and "federation." One conference, the Eastern College Athletic Conference Division II Wrestling League, uses both "conference" and "league" in its title, while College Hockey America eschews any collective term. Among the I 84 conferences under scrutiny here, 6I add "athletic" or "athletics" to their name (33\%), 44 incorporate "collegiate" or "intercollegiate" $(24 \%)$, I3 include "college" or "university" $(7 \%)$, and 2 interject "sports" ( $\mathrm{I} \%)$. Although beyond the scope of this project, one has to wonder why conferences prefer "athletic" or "athletics" over "sports." The literature is silent on the matter.

Athletic conference membership is advantageous to colleges and universities. Almost no independents remain among the four-year schools, with even the famously independent University of Notre Dame warming to conference affiliations in sports other than football. Woerlein (1938, I03) said, "Conferences have without a doubt placed college athletics on a much higher plane than they occupied before the formation of the first athletic conference." A conference builds rivalry, Suwanski wrote 40 years later, and gives "the players something to play for. As an independent, every game is the same" (I978). "New leagues continue to appear," said Abbott, "as emerging universities seek the publicity and identity provided by structured competition" (I990, 2II). Trani (1995) wrote that he and fellow university presidents viewed "conference affiliation as a source of stature for their institutions.” Suggs (2003, A37) said, “... a conference provides an identity" because, as then president Larry R. Faulkner of the University of Texas at Austin told Suggs, "a large fraction of the public's news about an institution comes from sports reporting."

Two sports professionals shared with me some advantages that they see their institutions derive from conference membership. On 3 I July 20I9, Mike Williams, an Assistant Director of Athletics at Illinois State University, said member schools ( $\mathrm{I}$ ) share revenue that comes to the conference from television 
deals and from conference schools playing in post-season tournaments; (2) can turn to conference headquarters for help in pleading a case for post-season atlarge tournament bids; (3) have easy access to video clips from the conference archive; (4) know that there are guaranteed opponents each year; and (5) get the chance to compete for conference-wide awards to athletes and to schools. Dennie Bridges, a retired athletics director and national championship basketball coach from Illinois Wesleyan University, told me on 6 November 2019 that "scheduling is the core advantage." You know what schools you are playing year after year, and in some sports that means a home game and an away game each season.

Mike Williams was referring to Illinois State's Missouri Valley Conference and Missouri Valley Football Conference affiliations and Dennie Bridges to Illinois Wesleyan's College Conference of Illinois and Wisconsin. These 3 were among the I 57 conferences in 20I9-2020 under the egis of the National Collegiate Athletic Association (NCAA). Another 23 conferences competed as a part of the National Association of Intercollegiate Athletics (NAIA), and one conference each looked to the United States Collegiate Athletic Association (USCAA) or the American Collegiate Athletic Association for guidance. Two other conferences, the Pacific Christian Athletic Conference and the Collegiate Sprint Football League, operated independently. Lemons $(2017,32)$ estimated that in 2016 roughly 460,000 athletes were competing for schools in NCAA conferences, 65,000 for NAIA, and I4,, 00 for USCAA (some of which included two-year colleges). Oversight organizations sponsor championship contests, make and enforce recruiting and in-game rules, collect statistics on sporting events/individuals, share revenue with member schools, promote the athletic programs of member schools, and otherwise attempt to keep athletic competition fair. They do not, however, tell colleges how to name their sports conferences (Trani I995).

How do conferences arrive at the naming decision for a new conference or replacement name for an existing conference? Name negotiations typically involve representatives from current members of an active conference or prospective members when a conference is in the formation stage. Sometimes the negotiators have included faculty appointed by their school's administration (St. Louis Post-Dispatch I907). More recently directors of athletics, presidents, and governing boards have taken greater active roles, with the presidents and boards reserving the authority to accept or reject membership and finalize the name of the conference. In addition to names originating with college officials, ideas for conference names have come in via solicitations of college students (Casper (Wyoming) Star-Tribune I937) and other fans (Wright I998), as well as through the work of paid consultants ("Rivers Rise" 2019).

As is typically the case in brand development discussions at the corporate level, the process of collegiate conference naming is often secretive, with spokespersons being noncommittal with reporters, saying things like "we tossed around some ideas." A contemporary account of a real-world instance in I963, however, offers insights into what takes place in those closed meeting rooms 
from which conferences emerge. Headquartered in Frisco, Texas, the Southland Conference is a NCAA enterprise with a compact distribution in 2019-2020 of I 3 schools in Texas, Louisiana, and Arkansas. During the spring of I963, representatives of the colleges that became the conference's six charter members met in Austin, Texas. Sportswriter Louis Hudson was able to learn details about the meeting from Ben Cook, the sports information director at one of the six, Arlington State College, Arlington, Texas. Hudson $(1963,6)$ wrote

Naming an athletic conference is not as easy as one might think. Coming up with a name for a new conference... took the bulk of the three-day meeting... The name Southland Conference emerged from the meeting room after eight hours of hectic hassling ... [during which] a list of seven rules concerning the name were drawn up.

Hudson did not list all the rules but noted that all 44 of the names initially submitted failed somewhere along the line. He reported that among the seven rules were specifications that the name be "geographically descriptive" and "typographically functional" so as to provide "harried headline writers" of newspapers an abbreviated way to convey the conference name (in this case SLC). Cook told Hudson that Southland was a compromise, "since it did not conform to all seven rules."

The main purposes of this research endeavor have been to learn the names of all the conferences to which colleges granting at least the baccalaureate degree belonged in 2019-2020 and to evaluate the names of said conferences with respect to geographical appropriateness. In other words, does the conference name reflect accurately the locations of its member-school campuses?

\section{Methodology}

Surprising to me and by far the most comprehensive and current sources of conference names are Wikipedia's "List of NCAA Conferences," "List of NAIA Conferences," and "List of USCAA Institutions," supplemented by its "List of College Athletic Conferences in the United States." Wikipedia in this instance is a better source than the NCAA, NAIA, or other oversight authorities. Using the Wikipedia lists, one can proceed, conference by conference, through the names of current full and associate/affiliate members, plus those of former conference members. Wikipedia authors, relying on conference and college websites, press coverage, and other sources, are quick to pick up on changes of conference membership. For instance, Wikipedia reported early that the St. Louis Intercollegiate Athletic Conference was set to lose one 2019-2020 member with the closure of MacMurray College in May 2020. Authors often preview coming changes in conference status or membership. The University of North Dakota is preparing to join the Missouri Valley Football Conference for the 2020-202I season, and the reincarnated Central Collegiate Hockey Association has been getting ready to drop pucks in 202I-2022 ("List of NCAA Conferences"). Conference websites provide excellent backup information as needed. 
Table 2. Conferences of Four Year Colleges and Universities not Having a Place-based Name, 2019-2020.

\begin{tabular}{ll}
\hline American Athletic Conference & Ivy League \\
American Collegiate Athletic Association & Landmark Conference \\
American Rivers Conference & Liberty League \\
Association of Independent Institutions & Metropolitan Swimming Conference \\
Big 12 Conference & Mountain Rim Gymnastics Conference \\
Big Sky Conference & National Christian College Athletic Association \\
Big Ten Conference & National Collegiate Hockey Conference \\
Centennial Conference & National Intercollegiate Women's Fencing Association \\
Coastal Collegiate Sports Association & North Coast Athletic Conference \\
College Hockey America & North Star Athletic Association \\
Collegiate Sprint Football League & Patriot League \\
Collegiate Water Polo Association & Patriot Rifle Conference \\
Commonwealth Coast Conference & Pioneer Football League \\
Commonwealth Coast Football Conference & Presidents' Athletic Conference \\
Conference USA & Red River Athletic Conference \\
Continental Volleyball Conference & River States Conference \\
Crossroads League & Skyline Conference \\
Frontier Conference & Summit League, The \\
Great America Rifle Conference & Sun Conference, The \\
Great American Conference & United Volleyball Conference \\
Horizon League & University Athletic Association \\
\hline
\end{tabular}

There were 184 athletic conferences to which only baccalaureate colleges and universities belonged in 2019-2020. More than two-thirds (I30 or $7 \mathrm{I} \%$ ) of these four-year athletic conferences sponsored competition in multiple sports, while the other 54 conferences were single sport arrangements. Seven conferences $(4 \%)$ existed just for competition among women athletes. In this study, I include only fully participating conference members. Thus I exclude affiliate or associate members who might participate in a single sport, such as Macalester College in football in the Midwest Conference. Conferences appear and disappear, perhaps as ambitious member schools jump conferences to seek more competition and status. Or schools with declining fortunes leave in order to play teams with which they can be more competitive. Once a conference falls below a half dozen members, conference viability becomes doubtful. Conference names and conference membership for future years, therefore, will differ from those that I employed for this analysis (Smith and Hattery 2017).

As Table 2 depicts, nearly a quarter, 42 of $184(23 \%)$, of the four-year athletic conferences did not have a name spatially specific enough for an armchair geographer to define accurately the territory their membership occupies. Most 33 of the 42 , or $79 \%$ ) were easy to exclude, like Big I2 Conference, Centennial Conference, Conference USA, Ivy League, National Christian College Athletic Association, and United Volleyball Conference. Granted, those who follow collegiate sports in the USA will know that the Big $I 2$ has a central plains legacy and that the Ivy League resides in New England and the Middle Atlantic states. There is nothing in their conference names, however, to clue one to these locations. 
American Rivers, Red River, and River States seem to have a solid place basis in their names. None are definitive as to which river or rivers they refer. Although Coastal Collegiate Sports Association and North Coast Athletic Conference look to have place-based names, neither specifies the coast in question. In fact, North Coast here points not to an oceanic connection but rather to the Great Lakes.

Four of the conferences that I ultimately placed in Table 2 and on the excluded list of 42 ( Iо\%) did pose a classification dilemma: Big Sky Conference, Commonwealth Coast Conference, Commonwealth Coast Football Conference, and The Sun Conference. Many associate "Big Sky Country" with the state of Montana, but the I I full-time member schools of the Big Sky Conference were not just in Montana but also in eight other western states. Four of the 50 states $(8 \%)$, Kentucky, Massachusetts, Pennsylvania, and Virginia, refer to themselves as a "commonwealth," though there is no legal difference between state and commonwealth. Massachusetts and Virginia clearly have an Atlantic Ocean coastline; and Pennsylvania does as well if one counts the estuary of the Delaware River. The Commonwealth of Massachusetts (along with Maine and Rhode Island) is the focus of the Commonwealth conferences; but the place basis of these conference names is confusing because Virginia, and perhaps Pennsylvania, also could qualify as the site of a "commonwealth coast." The Sun Conference has members in Georgia, South Carolina, and Florida (The Sunshine State); but the sun shines across the continent and not just in the Southeast. Any college or university, on the basis of sun presence, could qualify for this conference. So its name is not sufficiently space specific.

The $\mathrm{I}_{4} 2$ conferences remaining are the main focus of this study. Having confirmed that each of these conferences carries a name that guides the observer to the correct geographical area of the USA, the question for me was whether the main campuses of all member schools occupy a location in that area. If the answer is "yes," then the conference has an appropriate place-based name, geographically speaking. If not, the name is inappropriate, geographically speaking. Several tools aided me in making these 142 calls, not the least of which was more than a half century of experience as a professional geographer looking at the regional layout of the USA. Personal copies of paper atlases and online atlas sources, like Bing Maps, were occasionally helpful. When I had a question about how to delimit the modern major divisions of the country, for example, Midwest, Northwest, Southeast, I turned to a map available online that the Census Bureau has created (US Department of Commerce 2020). When there was uncertainty about the boundary details of physiographic divisions, like the Rocky Mountains or the Appalachians, I consulted maps and commentaries in Regional Geomorphology of the United States (Thornbury 1965) and the "Anglo-America" segment of Regional Geography of the World (Wheeler, Kostbade, and Thoman I96I). For watershed information, the Internet was a key source for maps, such as "Missouri Watershed Map." I used it to position the campus of Missouri State University with respect to nearby waterways 
heading northward across Springfield to the Missouri River and those southward to White River of Arkansas (Missouri Department of Natural Resources 2019).

\section{Results}

\subsection{Geographically accurate place-based conference names}

Almost two-thirds, 9I/I42 (64\%), of the place-based conferences have an appropriate place-based name, a name that is geographically accurate. Table 3 names these conferences in alphabetical order, from America East Conference to Wisconsin Intercollegiate Athletic Conference. When the conference name specifies a directional component ( 52 of 9I or $57 \%$ ), then the members all stand in that portion of the country, as in the case of the Big West Conference, Little East Conference, and Northeast Fencing Conference. Multistate regions (2 I of 9I or $23 \%$ ) appear appropriately in such conference names as Mid-Atlantic Rifle Conference, New England Collegiate Conference, and Upper Midwest Athletic Conference. Members of the Colonial Athletic Association, Colonial Hockey Conference, and Colonial States Athletic Conference were likewise somewhere within the states that emerged from the original $\mathrm{I}_{3}$ British colonies. Conferences that derive their names from physical divisions of the country show up on this list (6 of 9I or $7 \%$ ). For example, all Appalachian Athletic Conference member schools were somewhere in the southern Appalachian Highlands, with conference headquarters in Ashville, North Carolina, squarely within that physiographic division. The ro full members of the East Coast Conference were mainly in New York State, but also in Connecticut and the District of Columbia. All members were clearly overlooking the ocean or in a state that borders the Atlantic. The remaining I2 of 9I ( $13 \%)$ names reference states or a metropolitan area. Member schools of the College Conference of Illinois and Wisconsin were in one of those two states, just as members of the Obio Athletic Conference were all in Ohio; those of the Penn State University Athletic Conference were only in Pennsylvania; the eight members of the Empire 8 Conference were in New York, the Empire State; and the City University of New York Athletic Conference confined itself to four of the five city boroughs (Manhattan, Brooklyn, Queens, and The Bronx).

\subsection{Geographically inaccurate place-based conference names}

Table 4 lists the $5 \mathrm{I} / \mathrm{I} 42(36 \%)$ baccalaureate conferences with geographically inaccurate-place inappropriate-names, giving for each conference the number of 2019-2020 members, the number of misplaced members, and the percentage misplaced. Of the $5 \mathrm{I}$ conferences in Table 4, I6 (3I\%) had one member out of place, $27(53 \%)$ had between 2 and $5,4(8 \%)$ had $7-\mathrm{I} 3$ (but at least one where it should be), and 4 others $(8 \%)$ had all of their members somewhere other than 
Table 3. Conferences of Four Year Colleges and Universities with Geographically Accurate Place-based Names, 2019-2020.

\begin{tabular}{|c|c|}
\hline America East Conference & Mid-South Conference \\
\hline American Midwest Conference & Mid-States Football Association \\
\hline Appalachian Athletic Conference & Midwest Christian College Conference \\
\hline Atlantic East Conference & Midwest Collegiate Volleyball League \\
\hline Big South Conference & Midwest Conference \\
\hline Big West Conference & Midwest Fencing Conference \\
\hline California Collegiate Athletic Association & Midwest Lacrosse Conference \\
\hline Cascade Collegiate Conference & Midwest Women’s Lacrosse Conference \\
\hline Central Atlantic Collegiate Conference & Midwestern Intercollegiate Volleyball Association \\
\hline Central Collegiate Ski Association & Minnesota Intercollegiate Athletic Conference \\
\hline Central Intercollegiate Bowling Conference & Mountain West Conference \\
\hline City University of New York Athletic Conference & New England Collegiate Conference \\
\hline College Conference of Illinois and Wisconsin & New England Intercollegiate Fencing Conference \\
\hline Colonial Athletic Association & New England Women's and Men's Athletic Conference \\
\hline Colonial Hockey Conference & New England Women's Hockey Alliance \\
\hline Colonial States Athletic Conference & New Jersey Athletic Conference \\
\hline East Atlantic Gymnastics League & New South Intercollegiate Swim Conference \\
\hline East Coast Conference & North Atlantic Conference \\
\hline Eastern College Athletic Conf. Division II Field Hockey & North Eastern Athletic Conference \\
\hline Eastern College Athletic Conf. Division II Wrestling League & Northeast Conference \\
\hline Eastern College Athletic Conference Hockey & Northeast Fencing Conference \\
\hline Eastern Collegiate Football Conference & Northeast-10 Conference \\
\hline Eastern Intercollegiate Ski Association & Northeastern Intercollegiate Athletics Conference \\
\hline Eastern Intercollegiate Volleyball Association & Northern Athletics Collegiate Conference \\
\hline Eastern Intercollegiate Wrestling Association & Northern Collegiate Hockey Association \\
\hline Eastern Women's Fencing Conference & Northern Sun Intercollegiate Conference \\
\hline Empire 8 Conference & Northwest Conference \\
\hline Great Lakes Intercollegiate Athletic Conference & Ohio Athletic Conference \\
\hline Great Northeast Athletic Conference & Ohio River Lacrosse Conference \\
\hline Great Northwest Athletic Conference & Pacific Christian Athletic Conference \\
\hline Great Plains Athletic Conference & Pacific Collegiate Swim and Dive Conference \\
\hline Gulf Coast Athletic Conference & Pacific West Conference \\
\hline Gulf South Conference & Peach Belt Conference \\
\hline Heart of America Athletic Conference & Penn State University Athletic Conference \\
\hline Heartland Collegiate Athletic Conference & Southern Athletic Association \\
\hline Hockey East Association & Southern California Intercollegiate Athletic Conference \\
\hline Little East Conference & Southern Conference \\
\hline Massachusetts State Collegiate Athletic Conference & Southern States Athletic Conference \\
\hline Metro Atlantic Athletic Conference & Southland Conference \\
\hline Mid-America Intercollegiate Athletics Association & State University of New York Athletic Conference \\
\hline Mid-Atlantic Collegiate Fencing Association & Sun Belt Conference \\
\hline Mid-Atlantic Rifle Conference & Sunshine State Conference \\
\hline Middle Atlantic Conference & Upper Midwest Athletic Conference \\
\hline Middle Atlantic Conference Commonwealth & USA South Athletic Conference \\
\hline Middle Atlantic Conference Freedom & Wisconsin Intercollegiate Athletic Conference \\
\hline
\end{tabular}

the area that the conference name suggests. By conference, among the $5 \mathrm{I}$, members misplaced ranged from a low of $6 \%$ to, of course, 100\% for those with every member school out of place.

\subsubsection{At least one member school in place}

The venerable Southeastern Conference (SEC) was among I 6 conferences with just a single misplaced member. After the 2019 football season ended for the 
Table 4. Conferences of Four Year Colleges and Universities with at Least One Geographically Inaccurate Place-based Name, 2019-2020.

\begin{tabular}{|c|c|c|c|}
\hline Name of conference & $\begin{array}{c}\text { Total } \\
\text { members }\end{array}$ & $\begin{array}{c}\text { Misplaced } \\
\text { members }\end{array}$ & $\begin{array}{l}\text { Percent } \\
\text { misplaced }\end{array}$ \\
\hline Allegheny Mountain Collegiate Conference & 11 & 4 & 36 \\
\hline American Southwest Conference & 12 & 3 & 25 \\
\hline Atlantic 10 Conference & 14 & 1 & 7 \\
\hline Atlantic Coast Conference & 15 & 2 & 13 \\
\hline Atlantic Hockey Association & 11 & 1 & 9 \\
\hline Atlantic Sun Conference & 9 & 1 & 11 \\
\hline Big East Conference & 10 & 5 & 50 \\
\hline Bluegrass Mountain Conference & 7 & 1 & 14 \\
\hline California Pacific Conference & 13 & 3 & 23 \\
\hline Capital Athletic Conference & 6 & 6 & 100 \\
\hline Central Intercollegiate Athletic Association & 12 & 12 & 100 \\
\hline Chicagoland Collegiate Athletic Conference & 15 & 4 & 27 \\
\hline Conference Carolinas & 12 & 2 & 17 \\
\hline Eastern Association of Rowing Colleges & 18 & 1 & 6 \\
\hline $\begin{array}{l}\text { Eastern Association of Women's } \\
\text { Rowing Colleges }\end{array}$ & 18 & 1 & 6 \\
\hline Eastern Intercollegiate Gymnastics League & 5 & 1 & 20 \\
\hline Golden State Athletic Conference & 10 & 2 & 20 \\
\hline Great Lakes Valley Conference & 16 & 16 & 100 \\
\hline Great Midwest Athletic Conference & 13 & 4 & 31 \\
\hline $\begin{array}{l}\text { Intercollegiate Fencing Conference of } \\
\text { Southern California }\end{array}$ & 7 & 1 & 14 \\
\hline Kansas Collegiate Athletic Conference & 13 & 3 & 23 \\
\hline Lone Star Conference & 19 & 5 & 26 \\
\hline Michigan Intercollegiate Athletic Association & 9 & 2 & 22 \\
\hline Mid-American Conference & 12 & 1 & 8 \\
\hline Mid-Atlantic Rowing Conference & 13 & 3 & 23 \\
\hline Midwest Independent Conference & 6 & 2 & 33 \\
\hline Missouri Valley Conference & 10 & 10 & 100 \\
\hline Missouri Valley Football Conference & 10 & 8 & 80 \\
\hline Mountain East Conference & 12 & 2 & 17 \\
\hline Mountain Pacific Sports Federation & 41 & 4 & 10 \\
\hline New England Hockey Conference & 12 & 2 & 17 \\
\hline New England Small College Athletic Conference & 11 & 1 & 9 \\
\hline Ohio Valley Conference & 12 & 4 & 33 \\
\hline Old Dominion Athletic Conference & 15 & 1 & 7 \\
\hline Pac-12 Conference & 12 & 4 & 33 \\
\hline Pennsylvania State Athletic Conference & 18 & 1 & 6 \\
\hline Rocky Mountain Athletic Conference & 16 & 3 & 19 \\
\hline Rocky Mountain Intercollegiate Ski Association & 6 & 2 & 33 \\
\hline Sooner Athletic Conference & 11 & 5 & 45 \\
\hline South Atlantic Conference & 12 & 3 & 25 \\
\hline Southeastern Conference & 14 & 1 & 7 \\
\hline Southern Collegiate Athletic Conference & 10 & 2 & 20 \\
\hline Southern Intercollegiate Athletic Conference & 13 & 1 & 8 \\
\hline Southland Bowling League & 8 & 2 & 25 \\
\hline Southwestern Athletic Conference & 10 & 8 & 80 \\
\hline St. Louis Intercollegiate Athletic Conference & 10 & 7 & 70 \\
\hline West Coast Conference & 10 & 1 & 10 \\
\hline Western Athletic Conference & 9 & 1 & 11 \\
\hline Western Collegiate Hockey Association & 15 & 13 & 87 \\
\hline Western Water Polo Association & 15 & 4 & 27 \\
\hline Wolverine-Hoosier Athletic Conference & 12 & 2 & 17 \\
\hline
\end{tabular}


University of Missouri (Mizzou), this member of the SEC parted ways with its head football coach. Reporting on the coach's dismissal, an Associated Press release said that Missouri's flagship university faced tough issues in replacing Barry Odom, like low coach salaries compared to other SEC schools. In addition, "The school also resides outside the league's natural footprint and will forever battle SEC ... behemoths ... for both recruits and wins" (Skretta 20I9, B8). Mizzou is a latecomer to this nearly century-old, football-obsessed conference whose roots are in the Deep South. By adding Mizzou in 201 2, the SEC overreached its natural footprint.

Here are the reasons why the other I 5 conferences with one misplaced member ended up on the list of $5 \mathrm{I}$ in Table 4. The Tempe campus of Arizona State University (Intercollegiate Fencing Conference of Southern California) is not in California. Clinton, New York, near Lake Ontario, and site of Hamilton College, is not in New England; but Hamilton belonged in 2019-2020 to the New England Small College Athletic Conference. Guilford College (Old Dominion Atbletic Conference), though close to the Virginia border, is in North Carolina and not in the Old Dominion State. Shepherdstown, West Virginia, home of Shepherd University, is not in Pennsylvania; but this institution competed as a full member of the Pennsylvania State Athletic Conference. Savannah College of Art and Design (Bluegrass Mountain Conference), at coastal Savannah, Georgia, is far from the other six, mountain-based members of this swimming-only conference. The Eastern Association of Rowing Colleges counted I 8 members in this men's NCAA conference, of which 17 are in a contiguous band of states stretching from New Hampshire to Maryland. The I 8th member is the University of Wisconsin at Madison, several states and I200-I $300 \mathrm{~km}$ to the west of the conference core. The Madison campus also houses female crews that competed in the Eastern Association of Women's Rowing Colleges, where again all other member-school locations were near the eastern seaboard. Similarly, the Eastern Intercollegiate Gymnastics League included the University of Illinois at Chicago among its half dozen members. Wilberforce, Ohio, home of Central State University (Southern Intercollegiate Athletic Conference), is not in the South; and Brigham Young University's (West Coast Conference) Provo, Utah, campus lies roughly a thousand $\mathrm{km}$ from the western coast of North America. St. Louis University in St. Louis, Missouri (Atlantic Io Conference); the Air Force Academy, in Colorado Springs, Colorado (Atlantic Hockey Association); and Lipscomb University, in Nashville, Tennessee (Atlantic Sun Conference) are a long way from blue water. Buffalo, home of State University of New York at Buffalo (Mid-American Conference), is not what geographers deem middle American. Chicago State University (Western Athletic Conference), on the other hand, is near the middle of the USA, not in the West.

Among the 27 conferences with from two to five geographical misplacements, were two of the "Power Five" conferences: Atlantic Coast Conference (ACC) and Pac-I 2 Conference. Including also the SEC, Big Ten, and Big I2, the Power Five wield considerable influence over television revenue and enjoy advantages 
that lesser conferences do not possess. Brand value that the ACC had built since its 1953 founding surely made it an easy decision for the ACC to keep its original name when expanding far inland in 2013 to Indiana to add Notre Dame University, except for football, and likewise to Kentucky in 20I4 for the University of Louisville. Obviously, neither Indiana nor Kentucky lie anywhere near the Atlantic Ocean's coastline. Out West, the Pac-I2, formerly Pacific Coast Conference, had in 2019-2020 four misplaced members. In 1978, the conference added Arizona State University and the University of Arizona to what was then a California, Oregon, and Washington footprint. Later, in 20I I, the newly renamed Pac-I2 successfully admitted the universities of Utah and Colorado. The ACC was one of I I place-based conferences with two schools out of footprint, and the Pac-I2 was one of seven conferences having four misplacements. Of the remaining nine conferences in this group, six had three member schools out of place; and three included five campus locations out of sync vis-à-vis the conference names. Among those with five was the Lone Star Conference. One would expect members of the Lone Star to be in the Lone Star State, and all members were when the conference began (Commerce (Texas) Journal I93I). Expansion has pushed the conference beyond Texas to neighboring states Arkansas, New Mexico, and Oklahoma.

There were four conferences that had at least seven misplaced members-but also some presence within the name's footprint. Only two of the member campuses of the Missouri Valley Football Conference, those of South Dakota State University and the University of South Dakota, were in the watershed of the Missouri River, while eight $(80 \%)$ were not, with one (Youngstown State University) as far east as eastern Ohio. None of the ro members of the St. Louis Intercollegiate Athletic Conference were within the city limits of St. Louis, although three of them $(30 \%)$ Fontbonne University (Clayton, Missouri), Principia College (Elsah, Illinois), and Webster University (Webster Groves, Missouri) were in the St. Louis metropolitan area. Other members of this conference stretched from Mt. Pleasant, Iowa, to Fulton, Missouri, to Louisville, Kentucky. Oklahoma is the Sooner State; and the Sooner Athletic Conference included many schools from Oklahoma but had outliers in Arkansas, Kansas, and Texas, leaving 45\% misplaced. The Southwestern Athletic Conference did in 2019-2020 have two Texas locations (Houston and Prairie View); but the other eight locations $(80 \%)$ were in Alabama, Arkansas, Louisiana, and Mississippi-clearly not southwestern. Even the conference headquarters is in Birmingham, Alabama. The Western Collegiate Hockey Association has reached eastward as far as Bowling Green, Ohio, and southward to Huntsville, Alabama, to enlist schools wanting to participate in this NCAA Division I group of schools whose primary athletic conferences do not sponsor intercollegiate ice hockey. Of this conference's I 5 members in 2019-2020, $87 \%$ were out of footprint, leaving just the Anchorage and Fairbanks campuses of the University of Alaska in the West. 


\subsubsection{All member schools out of place}

Only 4 of the 5 I $(8 \%)$ conferences had a name so badly location challenged that not a single school was in the geographical area where one would expect to find conference members. Each of the 100\% geographically misnamed conferences merits a brief narrative.

The Capital Athletic Conference competes near the District of Columbia but does not have a member within the capital itself. Member locations included Salisbury and St. Mary's City, Maryland; York, Pennsylvania; and Buena Vista, Fredericksburg, and Newport News, Virginia. When the conference began in 1989, however, it counted among its members two within the District of Columbia, within the capital: The Catholic University of America and Gallaudet University (Pittsburgh Post-Gazette I989). The conference logo still features a profile of the capitol dome (Capital Athletic Conference 2020).

Charlotte, North Carolina, houses the headquarters of the Central Intercollegiate Athletic Association (CIAA). Its dozen member schools, mostly historically black colleges and universities, span the contiguous states of Pennsylvania, Maryland, Virginia, North Carolina, and South Carolina, not one of which lies in the central portion of the country, between the Appalachians and the Rocky Mountains. Dating from I9I2, the CIAA was initially the Colored Intercollegiate Athletic Association. Substitution in 1950 of "Central" for "Colored" allowed the CIAA to maintain its initialism but meant that the new name became locationally inappropriate (Austin (Texas) AmericanStatesman I993; "History of the CIAA" 2020).

Several urban places, many with baccalaureate colleges, occur within the Great Lakes watershed; but none of these colleges were 2019-2020 members of the Great Lakes Valley Conference (GLVC). Instead, the GLVC counted 9 of its I 6 members in Missouri, which does not border any of the lakes; 4 in Illinois; 2 in Indiana; and I across the Ohio in Kentucky. Lewis University, in the northeastern Illinois community of Romeoville, was the only member even close to the drainage divide separating the Great Lakes from the Mississippi Valley (Great Lakes Valley Conference 2020).

The Missouri River's watershed is huge, occupying one-sixth of North America and claiming about one-fourth of all the agricultural land in the United States. No river in the USA is longer than the Missouri's roughly $3700 \mathrm{~km}$. Yet not one of the ro members in 2019-2020 of the Missouri Valley Conference (MVC) was in the watershed, although Missouri State University's Springfield campus is just a few $\mathrm{km}$ beyond the southern edge. At the time of its founding in 1907, the $M V C$ counted three of the original members, the universities of Kansas, Missouri, and Nebraska, within the watershed (St. Louis Post-Dispatch 1907). Never, however, have all the members at any one time been within the Missouri River's enormous catchment area. The most recent watershed qualifier to leave the MVC was Creighton University (Omaha, Nebraska) in 2013. 


\section{Discussion and Conclusion}

The bad match between the member locations of the MVC and the conference name was the impetus for this study, as I watched conference membership over many years stray from the Missouri River basin, even as far off as West Texas State University (Canyon) and New Mexico State University (Las Cruces). So it was a bit of a surprise when so many names of place-based baccalaureate conferences turned out to have an excellent geographical connection (9I of I42) or only a few mislocated campuses. The $M V C$ model turned out to be the exception rather than the rule.

Having focused here on the four-year colleges and universities in the United States, it is possible to envision research on other categories of place-based athletic conferences. Two-year colleges compete in conferences with names. High schools in nearly every, if not every, state have conferences, often with a place basis in the name. Countries other than the United States, such as Canada, have named amateur conferences. At the professional level, minor league baseball has many conferences with a geographical flavor to their names, like the Midwest League, Texas League, or Pacific Coast League. A classification system such as the one I employ here would serve well in onomastic studies of such conferences.

Because of the COVID-I9 pandemic, the 20I9-2020 college athletics year ended prematurely when many winter sports terminated without the traditional post-season tournaments. Spring sports ended before the conference seasons got underway. Uncertainty pervades the sports scene at all levels, and it would not be surprising to see more conference realignment or even college and university closures for 2020-202I and following seasons than would have otherwise been the case. As of May 2020, the California Collegiate Athletic Association canceled all fall 2020 sports (Gregory 2020).

Frank Deford was by no means the only journalist to make light of conference names and the naming process; but conference names obviously matter in terms of brand awareness, marketing prowess, acronym hardiness, and logo value. Adding a full-time member school that does not fit the geographic footprint of the conference is often not enough impetus for a conference to change its name. After all, that outlier newcomer someday might find a better conference fit for themselves and abandon ship. And, as I have shown, sometimes the brand is so strong that conferences are willing to add and subtract member schools to the point when none stand within the geographic footprint that the longstanding conference name implies. Conference brands typically are too valuable to drop when the membership roster changes, especially in the highly competitive, highly lucrative upper echelon of collegiate sports in the United States.

\section{Acknowledgment}

Thanks go to Mark C. Jones, Bill Kemp, John Kostelnick, Wib Leonard, and the two anonymous reviewers of the manuscript. 


\section{Disclosure statement}

No potential conflict of interest was reported by the author(s).

\section{ORCID}

\section{Michael D. Sublett (D http://orcid.org/oooo-0ooI-6896-9940}

\section{Bibliography}

Abbott, Carl. I990. "College Athletic Conferences and American Regions." Journal of American Studies 24, no. 2: 2I I-22I.

Austin (Texas) American-Statesman. 1993, October 17. "Significant Events in Black College Football." Accessed July Io, 20I9. https://www.newspapers.com.

Capital Athletic Conference (website). Accessed February 27, 2020. https://www.cacsports.com/landing/ index.

Casper (Wyoming) Star-Tribune. 1937, October 24. “Wyoming Students Suggest 'Intermountain Seven' as Name for New Conference.” Accessed May 28, 20I9. https:/www.newspapers.com.

Christian Repository (Montpelier, Vermont). I868, June 20. “Missouri Liberal Conference.” Accessed May 2I, 20I9. https://www.newspapers.com.

Cincinnati Daily Press. I 859, October I2. "South-Eastern Conference of the Methodist Episcopal Church." Accessed July I, 20I9. https://www.newspapers.com.

Commerce (Texas) Journal. I93 I, August 21. "Lone Star Conference Gets Approval of Texas Association of Colleges." Accessed July II, 20I9. https://www.newspapers.com.

Courier-Journal (Louisville, Kentucky). I867, February 22. "Religious Services at the Unitarian Church." Accessed July 3, 20I9. https://www.newspapers.com.

Deford, Frank. 2012, September 19. “The Big East Conference: What's in a Name?” Morning Edition (NPR). Accessed February 24, 2020. https://www.npr.org/2012/09/I9/I6I342538/the-big-east-conference-whats-in-a-name.

El Paso (Texas) Herald. I909, July 5. "Stone Cutters Meet." Accessed July I I, 20I9. https://www.newspapers.com.

Great Lakes Valley Conference (website). Accessed June 22, 2020. http://www.glvcsports.com.

Gregory, Sean. 2020, June I and 8. "Play Ball-or Balk? The Risks and Rewards of Restarting Sports." TIME.

"History of the CIAA." Central Intercollegiate Athletic Conference (website). Accessed June 22, 2020. https://theciaa.com.

Hudson, Louis. 1963, April 8. "To Name a Conference ...." Grand Prairie (Texas) Daily News. Accessed July 8, 20I9. https://www.newspapers.com.

Lemons, Robert Scott. 2017. “Amateurism and the NCAA Cartel." In College Athletes' Rights and WellBeing, edited by Eddie Comeaux, 32-42. Baltimore, MD: Johns Hopkins University Press.

"List of College Athletic Conferences in the United States." Wikipedia: The Free Encyclopedia. Accessed February 27, 2020. https://en.wikipedia.org/wiki/List_of_college_athletic_conferences_in_the_United_ States.

"List of NAIA Conferences." Wikipedia: The Free Encyclopedia. Accessed February 25, 2020. https://en. wikipedia.org/wiki/List_of_NAIA_conferences.

"List of NCAA Conferences." Wikipedia: The Free Encyclopedia. Accessed June 22, 2020. https://en.wikipedia.org/wiki/List_of_NCAA_conferences.

"List of USCAA Institutions." Wikipedia: The Free Encyclopedia. Accessed February 25, 2020. https://en. wikipedia.org/wiki/List_of_USCAA_institutions.

Missouri Department of Natural Resources (website). "Missouri Watershed Map.” Accessed April 22, 20I9. https://dnr.mo.gov/env/wpp/watersheds.htm.

The New York Times. 1906, January 3. "Yachtsmen to Go Abroad.” Accessed July I, 2019. https://www. newspapers.com.

Pittsburgh Post-Gazette. I989, December 22. "College Football." Accessed July I2, 2019. https://www. newspapers.com. 
Pittsfield (Massachusetts) Sun. I828, April 3. "Central Conference." Accessed July 3, 2019. https://www. newspapers.com.

"Rivers Rise: Iowa Conference Now American Rivers Conference,” American Rivers Conference (website). Accessed June 20, 20I9. https://rollrivers.com/index.aspx.

Skretta, Dave. 2019, November 30. "Odom Gets Fired as Missouri Coach." Pantagraph (Bloomington, Illinois).

Smith, Earl and Angela J. Hattery. 2017. "Conference Realignment and the Evolution of New Organizational Forms." In College Athletes' Rights and Well-Being, edited by Eddie Comeaux, I I3-I27. Baltimore, MD: Johns Hopkins University Press.

Smith, Ronald A. 20II. "Intercollegiate Athletic Associations and Conferences." In Sports in America: From Colonial Times to the Twenty-First Century: An Encyclopedia, edited by Steven A. Riess, 487-492. Armonk, NY: Sharpe Reference.

St. Louis Post-Dispatch. I907, January I3. "Faculties Busy and Form Athletic Big 5 Conference." Accessed May 22, 2019. https://www.newspapers.com.

Suggs, Welch. 2003, May 30. "Conference Soap Opera Is Driven by Cash, but Cachet Matters, Too." The Chronicle of Higher Education. Accessed August 2, 20I9. https://www.chronicle.com/article/ConferenceSoap-Opera-Is/5509.

Summit County (Akron, Ohio) Beacon. I857, October 2I. "The Methodists and Slavery." Accessed July I 8, 20I9. https://www.newspapers.com.

Suwanski, Rich. I978, July I5. "Wesleyan Sees Conference as Problem Solver." Messenger-Inquirer (Owensboro, Kentucky). Accessed July II, 20I9. https://www.newspapers.com.

Thornbury, William D. I965. Regional Geomorphology of the United States. New York: John Wiley \& Sons, Inc.

Trani, Eugene P. 1995, March 17. "The Distorted Landscape of Intercollegiate Sports." The Chronicle of Higher Education. Accessed May I 5, 20I9. https://www.chronicle.com/article/The-Distorted-Landscapeof/85650.

Tucson Daily Citizen. I97I, July 2. "Engineers to Meet in Tucson.” Accessed July I, 20I9. https://www. newspapers.com.

US Department of Commerce. Census Bureau. "Census Regions and Divisions of the United States." Accessed June 22, 2020. https://www2.census.gov/geo/pdfs/maps-data/maps/reference/us_regdiv.pdf.

Wheeler, Jesse H., Jr., J. Trenton Kostbade, and Richard S. Thoman. I961. Regional Geography of the World: An Introductory Survey. New York: Holt, Rinehart and Winston.

Woerlein, George W. I938. "Intercollegiate Athletic Conferences: Their History and Significance.” Master's Thesis, The Ohio State University.

Wright, Rick. I998, June 3. "Name Game Fans Vote Early, Often.” Albuquerque Journal. Accessed May 22, 20I9. https://www.newspapers.com.

Correspondence to: Michael D. Sublett, Department of Geography, Geology, and the Environment, Illinois State University, Campus Box 4400, Normal, IL 6I790-4400, USA. Email: mdsuble@ilstu.edu 